\title{
Artes suntuarias medievales en el actual montaje del Museo Arqueológico Nacional
}

\author{
Ángela Franco Mata \\ Museo Arqueológico Nacional \\ angela.franco@movistar.es
}

\begin{abstract}
RESUMEN
Se analizan en el presente contexto las artes suntuarias medievales en el marco del actual montaje del Museo Arqueológico Nacional, así como la evolución histórico-artística en las culturas correspondientes desde los inicios de la Edad Media hasta su ocaso. Desde el tesoro de Guarrazar, pasando por importantes preseas islámicas, como el bote de Zamora, arquetas de marfil y tesoros nazaríes, artes medievales cristianas románicas, góticas y mudéjares, hasta desembocar en las artes llegadas de Europa, son objeto de estudio científico, además de una explícita finalidad didáctica y estética.
\end{abstract}

Palabras clave: Montaje, vitrina, panel, funerario, Crucifijo, arqueta, mezquita, iglesia.

\section{Medieval Sumptuary Arts in the Current Staging of the Museo Arqueo- lógico Nacional}

\begin{abstract}
This paper analyses the presence of Medieval sumptuary art in the current new assemblage of the National Archaeological Museum. The artistic and historical developments in the whole range of cultures since the early Middle Ages to its decline, are fully covered. The exhibition makes the visitor move from the Guarrazar Treasure, through the Islamic ivory carving jewels such as the Zamora box and other ivory caskets, then to the Nasrid golden jewels, to the medieval Christian art, Romanesque, Gothic and Mudéjar, to end up with a set of important art pieces from various European countries. The whole collection has been deeply studied and each piece is displayed within its context in order to offer a didactic and aesthetic experience.
\end{abstract}

Key words: Assemblage, showcase, panel, funerary art, crucifix, casket, mosque, church. 
Muchos años han transcurrido desde el montaje del Museo Arqueológico Nacional en los años 70, hasta el actual recién concluido. El artículo que escribí en 1987 permanece como documento de la exposición permanente del museo y en consecuencia, en el marco histórico ${ }^{1}$. En 2008, durante la dirección de Rubí Sanz Gamo se acometió el desmontaje y traslado de una gran cantidad de fondos a los almacenes del Ministerio en Alcalá-Meco, operación que duró aproximadamente un año. El 2009, comenzó el largo proceso de montaje, con las sucesivas etapas hasta coronarlo: distribución de espacios, selección de objetos y su vinculación con los textos que conforman los períodos del Medioevo. El primero de ellos, denominado Diocesis Hispaniarum, coincide cronológicamente con el mundo romano, y corresponde a la difusión del cristianismo, al que hemos designado Christiana Religio. Comprende los siglos IV y V. Sigue la cultura visigoda, con la capitalidad del reino en Toledo, y se desarrolla entre los siglos V y VII.

Un enclave bizantino de amplio abanico cronológico convive con la civilización occidental del s. V al XII. Las dos grandes culturas, reinos cristianos y al-Andalus, inundan el suelo hispánico en sucesivos avances y retrocesos, del s. VIII al XV, en la denominada reconquista, por medio de la cual los reinos cristianos van ampliando su área de acción hasta liquidar el cada vez más reducido reino nazarí. La cultura andalusí, sin embargo, penetró en la cristiana y viceversa, lo que originó una mixtificación que se ha dado en llamar, con más o menos fortuna, arte mudéjar ${ }^{2}$. Los contenidos textuales y la museología han sido elaborados en equipo por la autora de este trabajo, Isabel Arias Sánchez y Luis Balmaseda Muncharaz. Este último, hasta su jubilación en 2011, aportó gran sabiduría al conjunto de aspectos del montaje. Sergio Vidal, que le ha sucedido como conservador, durante los tres últimos años, ha contribuido con algunas aportaciones interesantes a completar el discurso museográfico.

En el marco de "El Rey y la Iglesia, pilares del reino" hemos montado la parte recuperada del tesoro de Guarrazar en el Museo Arqueológico Nacional, en una espléndida vitrina exenta, con la corona de Recesvinto presidiendo el conjunto de las coronas y cruces $^{3}$ (Fig. 1). Está formada por dos anchas piezas semicirculares articuladas mediante charnelas y pasadores formando un aro. La chapa de oro es lisa en el interior y decorada exteriormente con verdugones geométricos calados con hojitas distribuidos entre los simétricos cabujones de zafiros, perlas y granates. Junto a los bordes corre un friso de círculos secantes en relieve, generando cuadrifolias. Del interior penden cadenillas con veintidós letras con incrustaciones que confirman la dedicatoria: [R]ECCESVINTHVS REX OFERET. Del centro pende una cruz con zafiros

1 Á. FRANCO MATA, "Montaje de las salas de arte cristiano bajomedieval en el Museo Arqueológico Nacional", Boletín de la Asociación Nacional de Archiveros, Bibliotecarios, Arqueólogos y Documentalistas (ANABAD), 37 (1987), pp. 627-643.

2 R. LÓPEZ GUZMÁN, Arquitectura mudéjar, Madrid, 2005.

3 J. AMADOR DE LOS RÍOS, El arte latino-bizantino en España y las coronas visigodas de Guarrazar: Ensayo histórico crítico, Madrid, 1861; A. PEREA (ed.), El Tesoro visigodo de Guarrazar, Madrid, 2001; y L.J. BALMASEDA MUNCHARAZ, "Orfebrería epigrafiada de época visigoda en el Museo Arqueológico Nacional", VIII Jornadas Científicas sobre Documentación de la Hispania Altomedieval (siglos VI-X), Departamento de Ciencias y Técnicas Historiográficas, Universidad Complutense de Madrid, Madrid, 2009, pp. 11-42. 


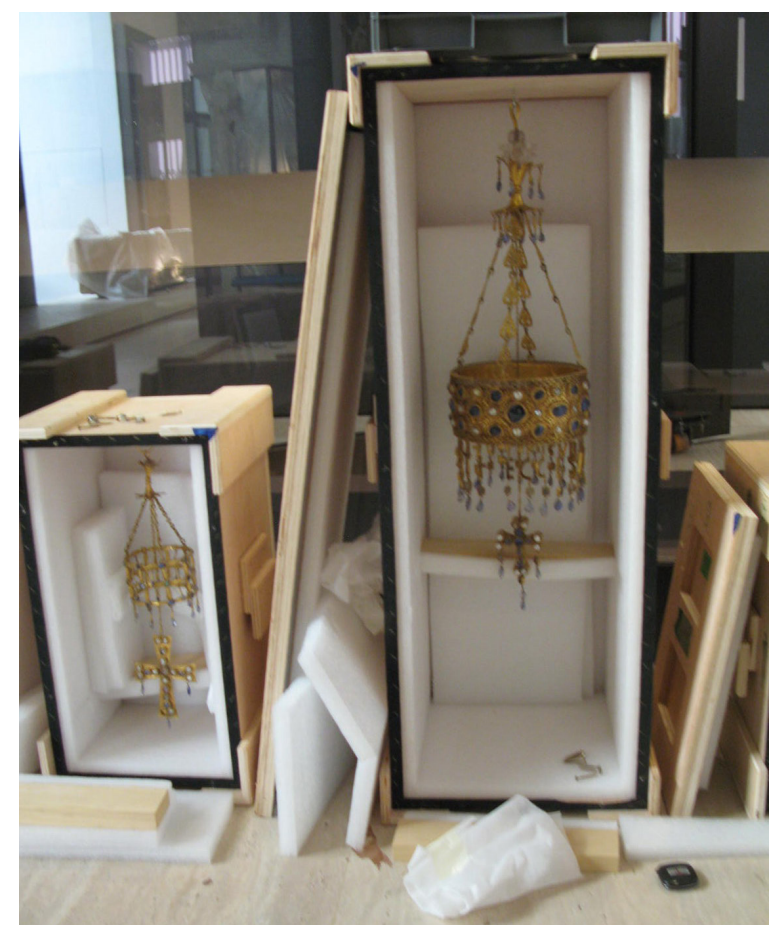

Fig. 1. Desembalaje de la corona de Recesvinto, tesoro de Guarrazar.

sin tallar en el anverso y repujada en el reverso, indudablemente reaprovechada de una cruz pectoral. Las restantes coronas son más sencillas. Las coronas eran ofrendas votivas de reyes abades y otros magnates, denominadas con alguna advocación. Dos brazos de cruz de oro, posiblemente sobre alma de madera tienen la típica estructura, de amplia incidencia en el arte medieval ${ }^{4}$. El tesoro representa el mejor ejemplo de la actividad de los talleres oficiales de la corte toledana, íntimamente influenciados por la tradición bizantina. El visitante puede, además de disfrutar de la contemplación de este tesoro, hallado de forma fortuita en Guarrazar, término de Guadamur (Toledo), ver un vídeo del tesoro conservado en el Museo Arqueológico Nacional, Musée du Moyen Âge, de París y el Palacio Real, de Madrid ${ }^{5}$. Junto al tesoro se exponen algunos fragmentos del tesoro de Torredonjimeno, repartido entre el Museo Arqueológico de Córdoba y el de Barcelona ${ }^{6}$.

4 Á. FRANCO MATA, "Evolución de la cruz visigoda en los Beatos", Torredonjimeno. Tesoro, monarquía y liturgia, catálogo exposición, Barcelona, 2003, pp. 109-115, y “Le trésor d'Oviedo, continuité de l'église wisigothique. Aspects stylistiques, iconographie et fonction", Les Cahiers de Saint-Michel de Cuxa, XLI (2010a), pp. 163-173.

5 Realizado por L. BALMASEDA, I. ARIAS, Á. FRANCO y S. VIDAL.

6 Torredonjimeno. Tesoro, monarquía y liturgia, catálogo exposición, Barcelona, 2003. 


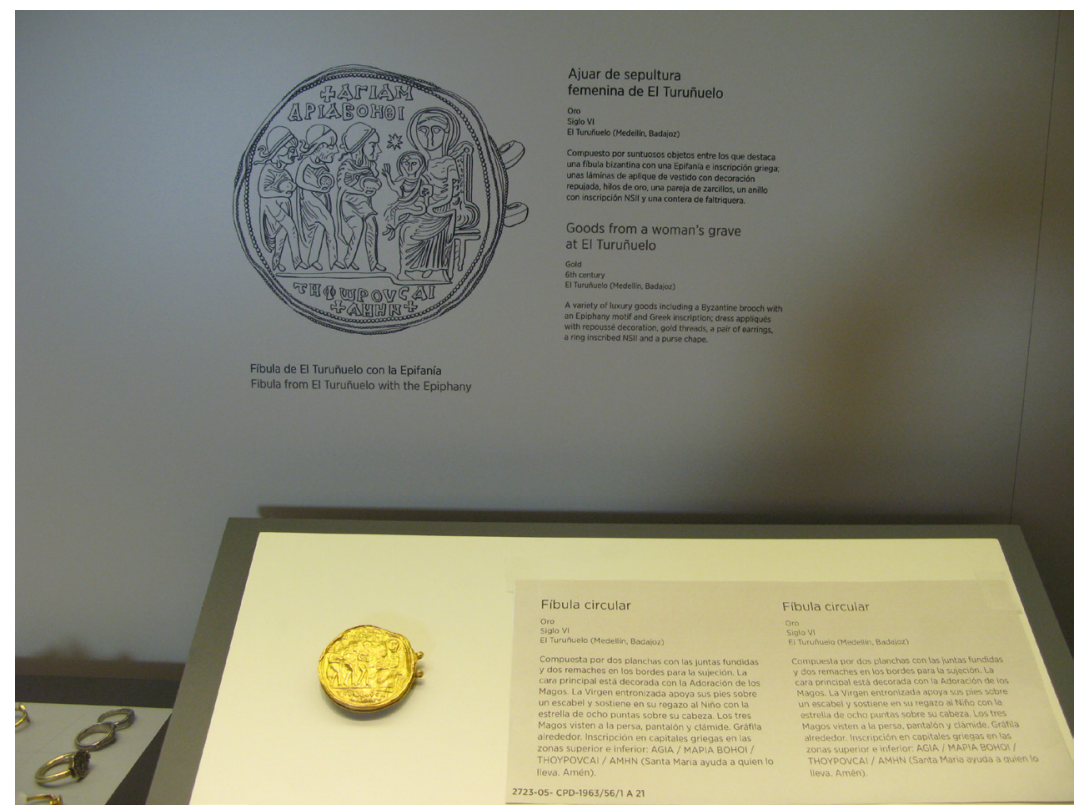

Fig. 2. Fíbula de Turuñuelo y dibujo.

Muchos tesoros visigodos están vinculados con la aristocracia. Pendientes, collares, anillos de oro y plata, broches de cinturón, fíbulas aquiliformes, las más representativas de los pueblos bárbaros, y otras piezas de orfebrería forman parte de este apartado. Las variadas procedencias contribuyen a profundizar en el conocimiento del estilo visigodo -Samos (Lugo), Huete (Cuenca), Puente Genil (Córdoba), Brácana (Granada)-, anillos firmados, y con entalles romanos, referencias al mundo clásico. Destaca la fíbula bizantina de oro con la representación de la Epifanía o Adoración de los Reyes Magos, acompañados de una inscripción que invoca a la Virgen María protección sobre la persona poseedora de la misma. Es similar a otra conservada en Salerno (Italia) y se conocen varios paralelos diseminados en diversos museos. Procede de una sepultura femenina de Turuñuelo Medellín (Badajoz) ${ }^{7}$ (Fig. 2). Para una mejor visión de la pieza, se ha acompañado de un dibujo explicativo. Junto a ella se hallaron unas láminas de oro, apliques de vestido decoradas con tema faunístico muy estilizado, además de un anillo con la inscripción NSII. Tal vez la fíbula así como brácteas, de clara raigambre oriental procedan de los recuerdos traídos de algún santuario palestino a donde la dama acudiera en peregrinación.

Entendemos el montaje de objetos de la sociedad visigoda con una visión didáctica, dedicando una vitrina a la tipología de broches de cinturón y fíbulas (Fig. 3). En los primeros distinguimos: broches de placa articulada con cabujones, de placa articulada con celdillas, de placa articulada con decoración moldeada, de placa rígida

7 M.J. PÉREZ MARTÍN, "Una tumba hispano-visigoda excepcional hallada en el Turuñuelo. Medellín (Badajoz)", Trabajos de Prehistoria, IV (1961), pp. 7-40. 


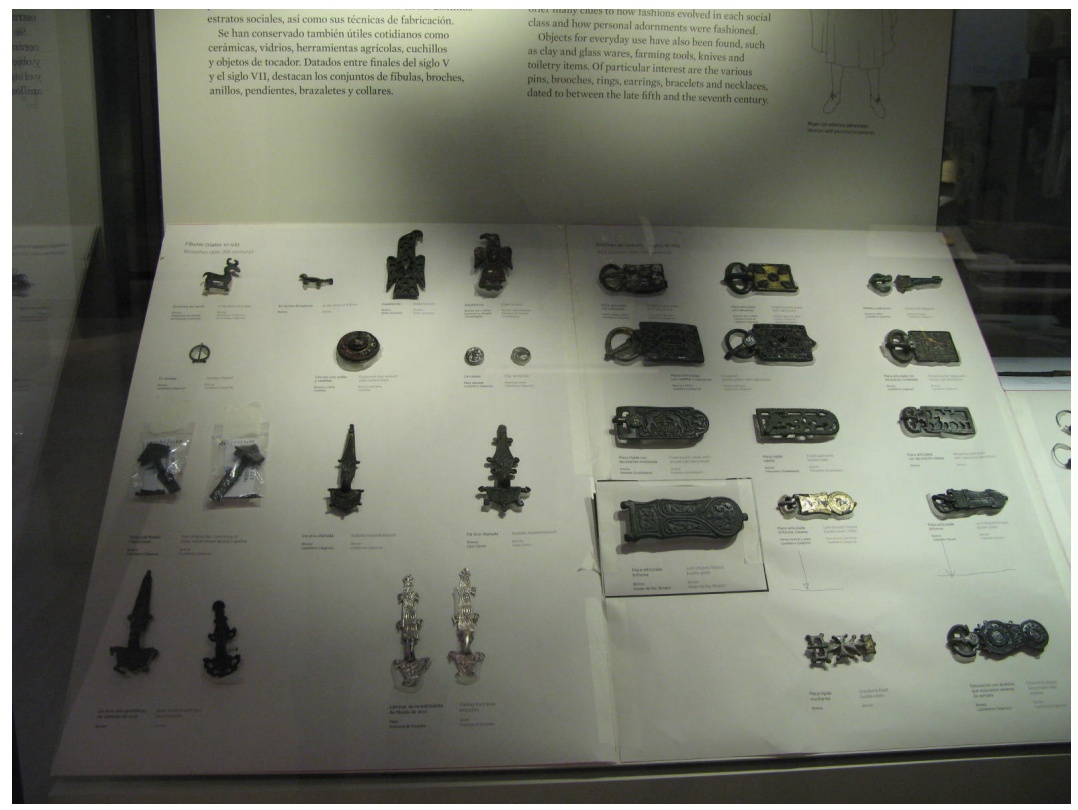

Fig. 3. Tipología de fíbulas y broches visigodos.

calada, de placa articulada con decoración calada, con decoración de alvéolos que estuvieron rellenos de esmalte, placa articulada liriforme y placa rígida cruciforme. Por lo que se refiere a las fíbulas, consideramos la tipología siguiente: en forma de ciervo, en forma de paloma, aquiliforme, en omega, de larga tradición, circular con umbo y celdillas, circulares, trilaminares, de arco digitada, de arco con apéndices.

Hemos puesto especial énfasis en el montaje de los ajuares de la necrópolis de Castiltierra (Segovia), cuyas excavaciones practicadas por Emilio Camps Cazorla y Joaquín $\mathrm{M}^{\mathrm{a}}$ de Navascués durante los años 1932 a 1935, proporcionaron una gran cantidad de ajuares, algunos particularmente ricos, con aretes de oro, collares de cuentas de ámbar, fíbulas de plata, un peine doble de hueso. Escasamente conocidos son los adornos del armamento, como los adornos de vaina o tahalí en forma de escudete, de oro. Los modélicos diarios de excavación nos han animado a insertar algunas páginas con fotos y textos. A partir de 1941 el seminario de Historia Primitiva del Hombre, dirigido por J. Martínez Santa Olalla efectuó dos campañas arqueológicas. Otras necrópolis, como Herrera de Pisuerga (Palencia), Carpio de Tajo (Toledo), Daganzo de Arriba (Madrid), Deza (Soria) contienen objetos suntuarios, aunque de menor entidad que la indicada.

El reducido capítulo que hemos bautizado como "El fin del Mare Nostrum" engloba diversos pueblos, vándalos, ostrogodos, visigodos y francos (ss. V-VII), los lombardos, en los siglos VII y VIII en Italia, hasta la invasión carolingia en el año 774. Tras sucesivas pérdidas territoriales y los devastadores efectos de la IV Cruzada (1204), el imperio de Oriente perdura hasta 1453, con la toma de Constantinopla por los turcos. Aunque son escasas las manifestaciones suntuarias, se exhiben piezas de gran cali- 
dad, como la cajita de plata sobredorada, del s. V, procedente de Sorpe (Lérida), cuyo probable destino fue el de guardar el anillo con el sello real con el que se certificaba la sanción de edictos y decisiones judiciales. Una ampollita de oro, con la inscripción EYM $\triangle O E A A C E N T Y$ en griego, expresa el deseo de una buena navegación, o tal vez fue usado como posible objeto funerario. Completan la exposición varios encolpia, cruces bivalvas para llevar colgadas al cuello, que se originan en Tierra Santa en el s. VI, y contienen pequeñas reliquias, como recuerdos para los peregrinos, placas de hueso, del s. XII, pertenecientes a cajas de rosetas, un anillo, una fíbula de arco, una cruz, una pareja de zarcillos, todo ello de oro, y cinco placas de cinturón unidas por charnelas, pertenecientes presumiblemente a un cinturón nupcial. Las placas van acompañadas de una imagen de una de las más hermosas cajas, la procedente de la catedral de Veroli (Italia), actualmente en el Victoria \& Albert Museum, de Londres.

Con el título de "Un nuevo espacio político del Islam en Occidente" hemos titulado el largo capítulo de la estancia de los musulmanes en al-Andalus. Si la primera etapa (711-756) se configuró como provincia del imperio omeya, gobernada por un emir dependiente de Damasco, en 756 la dinastía fue derrocada por los abasíes. Abd al-Rahman, príncipe omeya superviviente, huyó de Damasco y se refugió en el norte de África, conquistó Córdoba y fundó la dinastía omeya en al-Andalus, que perduró hasta 1031. Los cristianos eran considerados y respetados, como los judíos, siendo considerados "gentes del libro". Los impuestos sobre la población de cristiana, los mozárabes, fueron concluyentes para su conversión al nuevo credo.

En 929 con la instauración del califato el esplendor de Córdoba alcanzó su máximo apogeo, convirtiéndose en uno de los grandes centros difusores de cultura. Gobernada por los califas omeyas, la ruina del califato conduce a la disgregación del poder en multitud de reinos independientes, los denominados reinos de taifas. Además de la gran mezquita de Córdoba, se construyó la fastuosa ciudad palatina de Madinat al-Zahra (Ciudad Brillante), símbolo del poder e influyente en la Europa cristiana ${ }^{8}$. $\mathrm{Su}$ destrucción supuso una enorme pérdida artística, como la desaparecida Madinat al-Zahira, la ciudad construida por Almanzor, cuyo único elemento superviviente es la pila de abluciones de mármol que lleva su nombre, en el Museo Arqueológico Nacional.

Hemos introducido una novedad expositiva, a través de la cual esperamos conseguir un goce estético y sobre todo una enseñanza práctica: me refiero al montaje de la maqueta de la mezquita de Córdoba, de $6 \times 7$ metros en alto, cuya visión desde abajo de las sucesivas etapas constructivas viene refrendada por un plano, donde aquellas quedan indicadas por medio de distintos colores (Fig. 4). El espacio conformado ha sido limitado por doble fila de capiteles y basas, perfectamente visibles, y su acceso se abre con el surtidor de fuente en forma de cierva de bronce grabado y sobredorado. Ingresó en el Museo Arqueológico Nacional por compra el 3 de febrero de 1940. Por análisis estilístico, aunque la cierva de Madrid es más pequeña y menos estilizada que otros ejemplares, presenta claras similitudes con otras dos piezas aparecidas en el s. XVI entre las ruinas del palacio de Madinat al-Zahra. Una de ellas se encuentra en el

8 R. VELÁZQUEZ BOSCO, Madina Azzahara y Alamiriya, Madrid, 1912. 


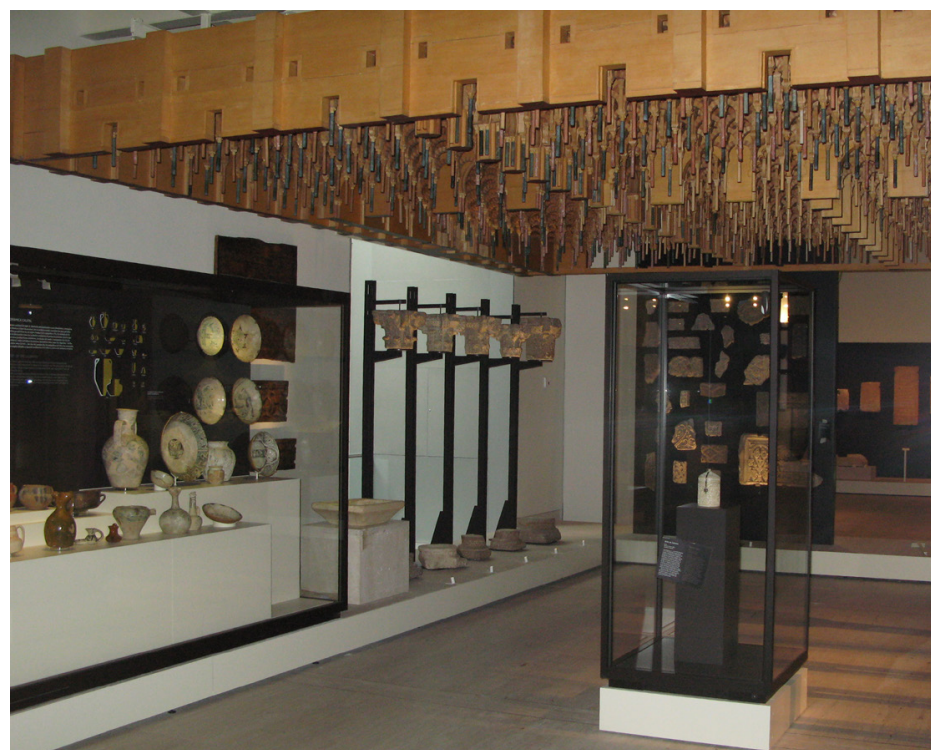

Fig. 4. Recreación artística del s. X en Córdoba: maqueta de la mezquita, vitrina del bote de Zamora, vitrina de cerámica, capiteles y basas.

Museo Arqueológico de Córdoba. La segunda, desaparecida a principios del s. XIX del Monasterio de Guadalupe, donde había sido depositada, ha sido recientemente recuperada y se halla desde 1997 en el Museo Nacional de Qatar'

Se ha dedicado una vitrina a la vajilla palaciega de cerámica, que constituye un precedente de la cerámica de Paterna ${ }^{10}$. Variados objetos, cuencos, platos, ataifores constituyen los recipientes fundamentales obrados a mediados del s. X (324-366 H. / 936-976 d.C.). Madinat al-Zahra fue el centro productor y difusor más importante de la cerámica vidriada y decorada en verde y manganeso durante el califato. Ornamentalmente, la nitidez del diseño y la austeridad de las composiciones, con amplias zonas del fondo sin decorar, la diferencian de otras producciones contemporáneas de al-Andalus. La función de este tipo de cerámica aún no se ha definido, pero está claro que la producción de Madinat al-Zahra supuso un avance técnico fundamental. El uso de óxidos de cobre y manganeso en la decoración y el vidriado que impermeabilizaba

9 E. CAMPS CAZORLA, "Un nuevo ciervo califal de bronce", Archivo Español de Arte, XVI (1943), pp. 212-222; E. CAMPS CAZORLA, "Ciervo califal de bronce", Adquisiciones del Museo Arqueológico Nacional (1940-1945), Madrid, 1947; M. GÓMEZ MORENO, El arte árabe español hasta los almohades. Arte mozárabe, Ars Hispaniae, vol. III, Madrid, 1951, p. 336; El esplendor de los omeyas cordobeses, catálogo de la exposición, Granada, 2001; y J. ZOZAYA, "Importaciones casuales en al-Andalus: las vías de comercio", Actas del IV Congreso de Arqueología Medieval española, vol. I, Alicante, 1993, p. 125.

10 E. CAMPS CAZORLA, "Cerámica y vidrios califales de Medina Zahara", Adquisiciones del Museo Arqueológico Nacional (1940-1945), Madrid, 1947, p. 154; R. CASTEJÓN Y MARTÍNEZ DE ARIZALA, Excavaciones del plan nacional de Medina Azahara (Córdoba). Campaña de 1943, Madrid, 1945; El esplendor de los omeyas cordobeses, catálogo exposición, Granada, 2001; y M. SÁNCHEZ LLORENTE, "Surtidor de fuente", Museo sin fronteras (2005). 
los recipientes evitando que las sustancias impregnasen el barro generó un tipo de vajilla especial, considerada de lujo ${ }^{11}$. Hemos acompañado la exposición de un cuadro informativo sobre la tipología de las cerámicas califales. Preside dicho espacio el bote de Zamora, descubierto en la catedral por doña Elena Gómez Moreno, obra de marfil, datada en el 353 de la Hégira (964) ${ }^{12}$. Expuesto en una vitrina exenta, es visible desde todos los puntos, pero hemos acompañado el deleite de su contemplación con un interactivo con imágenes de alta resolución. El bote y otra arqueta de la misma procedencia ( $\mathrm{n}^{\mathrm{o}}$ inv. 51944), expuesta en otra vitrina, han sufrido diversos avatares, y gracias a la eficaz intervención de Gómez Moreno y Guillermo de Osma, no han pasado a formar parte de las colecciones de la Hispanic Society, de Nueva York ${ }^{13}$.

Además del florecimiento de las ciudades, el comercio internacional fue muy significativo, destacando las rutas hacia el norte de África ${ }^{14}$. Se ha dedicado una vitrina con objetos productos de importaciones, como el bote para guardar kohl o cloruro de antimonio, utilizado como cosmético, fatimí (327-400 H. / 939-1010 d.C.) decorado con fauna y flora y la inscripción en caracteres cúficos "Bendición de Dios"15. Para observar con precisión los elementos indicados, hemos acompañado la información de varios dibujos arqueológicos realizados desde distintos puntos, anverso, reverso y caras laterales. Un ungüentario de pasta vítrea con tapón de oro, utilizado como perfumero, siglos VII-VIII, es una muestra del refinamiento en este tipo de objetos suntuarios. Procedente de Túnez es la arqueta de al-Mansuriyya (Túnez) con bordes recuadrados con placas de marfil policromadas e inscripción en caracteres cúficos, procedente de Carrión de los Condes, a donde llegó indudablemente como producto de botín de guerra, y al Museo como venta de Mariano Pérez Mínguez ${ }^{16}$.

Las actividades económicas se manifiestan de diversas formas, entre las que figuran oficios manuales, como la cerámica, sastrería, metalistería y orfebrería entre otros. Mostramos varios moldes de orfebre, algunas cuentas de collar de oro y plata,

11 M. SÁNCHEZ LLORENTE, “Ataifor”, Museo sin fronteras (2005).

12 J. FERRANDIS, Marfiles árabes de Occidente, vol. I, Madrid, 1935, pp. 56-58; J. BECKWITH, Caskets from Cordoba, Londres, 1985, pp. 10-13; Á. FRANCO MATA, "Bote de Zamora", Remembranza. Las Edades del Hombre, Zamora, 2001, p. 65, n 6, y "Bote de Zamora", Museo sin fronteras (2005); M. GÓMEZ MORENO, Catálogo monumental de la provincia de Zamora, Madrid, 1927, pp. 77-79, nº 164; B. MONTOYA TEJADA y B. MONTOYA DÍAZ, Marfiles cordobeses, Córdoba, 1979, pp. 24-26; J.I. MARTÍN BENITO y F. REGUERAS GRANDE, "El Bote de Zamora: historia y patrimonio", De Arte, 2 (2003), pp. 203-223; y Á. GALÁN Y GALINDO, "Los marfiles musulmanes del Museo Arqueológico Nacional, Boletín del Museo Arqueológico Nacional, 21-22-23 (2003-2004-2005), pp. 53-57.

13 J.I. MARTÍN BENITO y F. REGUERAS GRANDE, op. cit. (2003).

14 F. VALDÉS, "Aspectos comerciales de la economía peninsular durante el período de los Reinos de Taifas", Cuadernos de Prehistoria y Arqueología. Universidad Autónoma de Madrid, 18 (1991), pp. $319-330$.

15 M. SÁNCHEZ LLORENTE, "Bote de kohl”, Museo sin fronteras (2005); J. CAMÓN AZNAR, "Las piezas de cristal de roca y arte fatimí encontradas en España", Al-Andalus, 4 (1939), pp. 396-405; M. CASAMAR y F. VALDÉS, "Les objets égyptiens en cristal de roche dans al-Andalus, éléments pour une reflexion archéologique", L'Egypte fatimide, son art et son histoire, París, 1999; K. ERDMAN, "Fatimid rock crystal", Oriental Art, 3 (1951), pp. 142-146; El esplendor de los omeyas cordobeses, op. cit., 2001, p. 82; J. ZOZAYA, op. cit., 1993, p. 125; y R. GARCÍA GIMÉNEZ y F. VALDÉS FERNÁNDEZ, “Acerca del origen y de la cronología de los cristales de roca llamados fatimíes: el vidrio de Badajoz y la botella de Astorga", Cuadernos de Prehistoria y Arqueología. Universidad Autónoma de Madrid, 23 (1996), pp. 260-276.

16 Á. GALÁN Y GALINDO, op. cit. (2003-2005), pp. 48-50. 
así como una nutrida colección de anillos de plata. El montaje en una vitrina exenta facilita su correcta visión desde todos los ángulos.

El fin del califato cordobés originó la aparición de pequeños reinos de taifas, entre los que sobresalen Zaragoza, Toledo y Sevilla y dio como resultado la ampliación de las fronteras de los estados cristianos, que consolidaron progresivamente su expansión y propició la invasión de los almorávides (1086), dinastía musulmana del norte de África, a la que seguirá la de los almohades en 1146, que harán de Sevilla su capital. El Museo cuenta con importantes preseas de eboraria, que hemos instalado en una vitrina exenta. Destaca la arqueta, datada en el año 441 de la Hégira (10491050 d.C.), que conserva el nombre de la catedral de Palencia, donde fue hallada y utilizada como relicario. Sin embargo, sabemos por la inscripción laudatoria que fue realizada en los talleres de Cuenca, ciudad que en aquel momento pertenecía a la taifa de Toledo. Fue encargada por Ismail ben al Ma'amun, hijo del entonces soberano reinante Yahya al Ma'amun. Está decorada a base de placas de marfil sobre alma de madera, en un rítmico sistema de atauriques con hojas digitadas y anilladas, gacelas, grifos afrontados, león atacando y ballesteros cazando ${ }^{17}$. De la catedral de Zamora procede una arqueta de marfil almorávide (479-537 H. / 1086-1143 d.C.), con herrajes de plata nielada y una inscripción. Presenta abundante decoración islámica tallada de cartelas lobuladas con perros y leopardos persiguiendo gacelas, liebres huyendo de canes, aves con algún adorno vegetal estilizado, sobre fondos coloreados de azul y matizados con toques rojos y verdes. Ciertos cogollos con hojas largas recuerdan temas de origen sasánida. Una inscripción en caracteres cúficos, que bordea las cuatro caras de la tapa, pide la bendición de Dios a Mahoma y desea dicha y felicidad al dueño del objeto. Ha sido vinculada a Sevilla por el estilo de los caracteres de la inscripción. Unos documentos en pergamino, con cuentas y dibujos de aves y un personaje humano, la ponen en relación con el arte siciliano de finales del s. XII. A esta propuesta se opone otra que adelanta la pieza a fines del s. XI ${ }^{18}$. Una arqueta de madera de ébano decorada con taracea de hueso pintado, lleva una inscripción alusiva al emir Muhamamad ibn 'Abbad al-Mu'tamid, rey de Sevilla entre 1069 y 1091; procede de San Isidoro de León ${ }^{19}$.

Bajo el título de "El Reino nazarí, paradigma del refinamiento" hemos deseado significar el grado de distinción y elegancia que impregnó el reino de Granada, que comprendía las actuales provincias de Málaga, Granada y Almería, en el ocaso de su existencia. Vivió un difícil equilibrio político, siempre bajo la presión del reino de

17 R. AMADOR DE LOS RÍOS, “Arquetas arábigas de plata y marfil”, Museo Español de Antigüedades, vol. VIII, 1877, pp. 529-549; Á. FRANCO MATA, "La eboraria de los reinos hispánicos durante los siglos XI y XII", La Península Ibérica y el Mediterráneo entre los siglos XI y XII. Codex Aquilarensis. Cuadernos de Investigación del Monasterio de Santa María la Real, 13 (1998), pp. 143-166; M. GÓMEZ MORENO, El arte en España: guía del Museo del Palacio Nacional, Barcelona, 1929, p. 66, n 2585; Al-Andalus: las artes islámicas en España, catálogo exposición, Madrid, 1992, p. 204, n 7; Al-Andalus: The Islamic Arts in Spain, catálogo exposición, Nueva York, 1992; J. ZOZAYA, "Los marfiles de Cuenca", Cuenca, mil años de arte, Cuenca, 1999, pp. 75-114; Á. GALÁN Y GALINDO, op. cit. (2003-2005), pp. 57-62; y Á. FRANCO MATA, "Arqueta de la catedral de Palencia", Museo sin fronteras (2005).

18 Á. FRANCO MATA, "Arqueta de la catedral de Zamora", Museo sin fronteras (2005).

19 Á. FRANCO MATA, Arte leonés fuera de León (s. IV-XVI), León, 2010b, pp. 55-57. 
Castilla por el norte y de los meriníes del Magreb por el sur. Estas circunstancias no impidieron la existencia de una próspera economía gracias a la agricultura y excelente posición en las rutas comerciales entre África y Europa. Granada se convierte en una espléndida ciudad y se acomete la construcción del magnífico conjunto palaciego de la Alhambra. La debilidad política, sin embargo, se conjura con este espejismo, intensificándose las intervenciones militares castellanas, hasta la conquista de la capital por los Reyes Católicos al iniciarse el año 1492. Los sucesivos avances de la reconquista hasta la definitiva toma de Granada se reflejan iconográficamente en la sillería baja de la catedral de Toledo, testimonio fehaciente de las sucesivas tomas de ciudades $^{20}$.

Las artes suntuarias son de muy variado carácter, puesto que el refinamiento inundaba la vida de la corte granadina. La joyería tiene su más brillante representación en los tesoros de Bentarique (Almería), Mondújar (Granada) ${ }^{21}$, ambos en el Museo Arqueológico Nacional, y Bérchules (Metropolitan Museum of Art, de Nueva York) ${ }^{22}$. Los del Museo Arqueológico Nacional se hallan actualmente muy disminuidos a consecuencia de un robo perpetrado en la propia institución en 1894. Estos tesoros, junto a otros localizados, como el de Garrucha, tuvieron gran importancia durante los siglos del reino nazarí. Todos ellos han aparecido fortuitamente, por lo que no resulta fácil proponer la ubicación de algún taller del que saldrían estas piezas, más importantes por su brillantez que por la cantidad de oro usado, siempre en finísimas láminas. Predominan las técnicas de lámina calada, filigrana y granulado. Destacan los sartales, bien de pequeños aljófares o de pasadores oblongos o alcauciles, ambos con colgantes o alcorcíes decorados. Los brazaletes de oro se componen de dos finísimas láminas rellenas de pasta resinosa o almáciga. Los aquí presentados, sobre plintos individuales, para destacar su ostentación, son datables entre 629-898 H. / 1232-1492 d.C. ${ }^{23}$. Los brazaletes de plata también son huecos y eventualmente de filigrana. Estas joyas se destinaban a las jóvenes ricas como regalo de matrimonio. La vitrina donde se exponen estas preseas es exenta, y presenta distintos niveles con el fin de proporcionar una vista variada sobre un efecto estético intencionado de acuerdo con la naturaleza de las piezas. Los dos collares han sido montados sobre finos armazones para verse colgando ${ }^{24}$.

20 Á. FRANCO MATA, "La conquista de Granada en imágenes: la sillería baja de la catedral de Toledo, de Rodrigo Alemán", Ysabel. La Reina Católica. Una mirada desde la Catedral Primada, catálogo exposición, Toledo, 2005, pp. 350-353.

21 R. AMADOR DE LOS RÍOS, "Informe acerca de las joyas arábigas halladas en el año 1896 en las inmediaciones de Bentarique", Boletín de la Real Academia de Bellas Artes de San Fernando, XIX (1899), pp. 6-21; P.M. ARTIÑANO, Catálogo de la exposición de orfebrería civil española, Madrid, 1925, pp. 53-54; J. DE CASTRO Y SERRANO, "Joyas moriscas", La Ilustración Española y Americana, 13 de diciembre de 1887; F. JANER, De las joyas árabes de oro que se conservan en el Museo Arqueológico Nacional, Madrid, 1875; M. JENKINS y M. KEENE, Islamic Jewelry in the Metropolitan Museum of Art, Nueva York, 1982; y J. ZOZAYA, "Piezas de collar”, Al-Andalus. Las artes islámicas en España, op. cit., 1992, p. 302, n 73

22 R. AMADOR DE LOS RÍOS, op. cit. (1899), pp. 7-11; J. DE CASTRO Y SERRANO, op. cit. 1887; F. JANER, op. cit., 1875; P.M. ARTIÑANO, op. cit., 1925, pp. 53-54; y L. TORRES BALBÁS, Arte almohade, arte nazarí, arte mudéjar, Ars Hispaniae, vol. IV, Madrid, 1949, p. 229, fig. 251.

23 Á. FRANCO MATA, "Brazalete", Museo sin fronteras (2005).

24 Á. FRANCO MATA, "Collar", Museo sin fronteras (2005). 


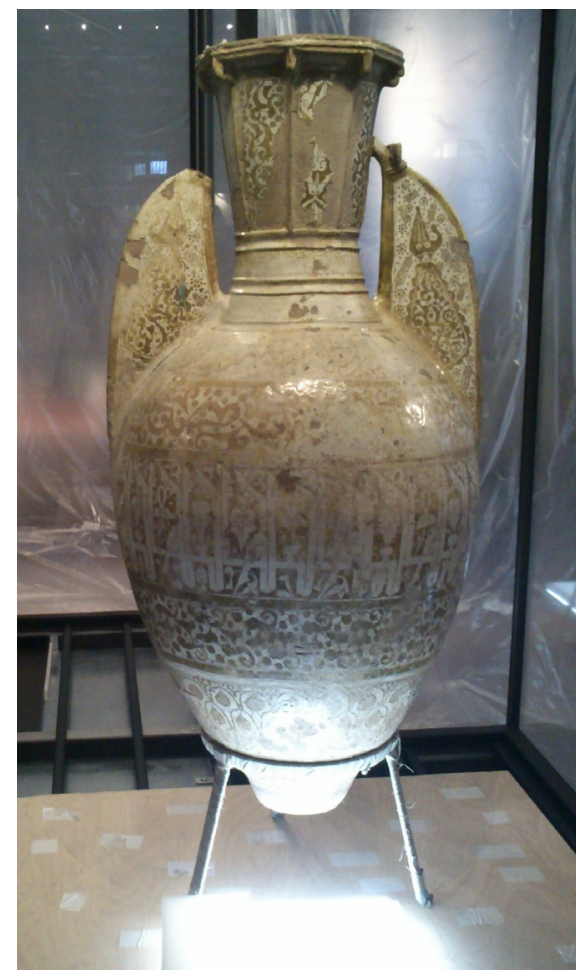

Fig. 5. Iluminación del jarrón de Jerez.

En el marco de la ornamentación de los palacios se integran los denominados "jarrones de la Alhambra" o "vasos de la Alhambra", aunque su producción remite a alfares de Málaga, como se refleja en la documentación. El Museo Arqueológico Nacional cuenta con dos ejemplares soberbios, montados en sendas vitrinas adyacentes, cuyos efectos visuales vienen determinados por los distintos ángulos de visión, entre ellos un engaño en la visión. Fueron hallados casualmente, el más antiguo, a principios del s. XX, al hacer obras para la consolidación de unas bóvedas en la cartuja de Santa María de la Defensión de Jerez de la Frontera (Cádiz). Ingresó en el Museo Arqueológico Nacional por donación el 29 de julio de 1930 (Fig. 5). El de Hornos fue descubierto por un labriego al arar en un campo de Jaén. Los vasos de la Alhambra constituyen las piezas más importantes de la producción cerámica nazarí. La delicadeza de su decoración y su gran tamaño hicieron que estas piezas adquirieran gran fama y se exportaran a otros lugares. Los ejemplares mejor conservados se encuentran en Palermo (Museo Regional de Sicilia), San Petersburgo (Museo del Ermitage), Estocolmo (Museo Nacional de Bellas Artes), Granada (Museo de la Alhambra) y Madrid (Instituto Valencia de Don Juan y Museo Arqueológico Nacional). Unos están decorados exclusivamente en dorado y otros en dorado y azul de cobalto, siempre sobre el fondo blanco del vidriado estannífero. Aunque su forma deriva de las gran- 
des vasijas de almacenaje, su tamaño de difícil manejo y la ausencia de elementos de presión en las asas hacen pensar en una función exclusivamente ornamental ${ }^{25}$. Obra de extraordinaria calidad y elegancia, procedente de la Alhambra es un acetre, recipiente metálico con asa que se usaba para arrojar agua sobre los pavimentos calientes de mármol y producir el vapor necesario en los baños. Pertenece al tipo de objetos domésticos usados en ambientes refinados e influidos por las modas orientales, de gran incidencia en al-Andalus. La estructura remite al mundo persa, que a partir del s. XII revitalizó las viejas formas romanas. Decoración de ataurique e inscripciones relativas a la felicidad ocupan la superficie ${ }^{26}$. Se ha montado ladeada con el fin de contemplar la refinada ornamentación.

El status de la caballería también tuvo una etapa de esplendor durante el período nazarí. Aunque el armamento andalusí conservado es muy escaso, hay que destacar un conjunto de espadas nazaríes conocidas como "jinetas". Su importancia radica tanto en la originalidad de sus empuñaduras, sin parangón en la época, como en el hecho de ser una producción genuinamente nazarí de armas de lujo. Esta pieza, sin dejar de ser un objeto suntuario, pertenece a una variante cuya decoración, basada en el azófar y el nielado, carece de la riqueza que caracteriza a otras espadas jinetas, realizadas en marfil o esmalte. Una espada jineta del s. XV (629-898 H. /1232-1492 d.C.) ingresó en el Museo Arqueológico Nacional por donación del cura párroco de la iglesia de San Marcelo (León), gracias a la mediación de Rodrigo Amador de los Ríos, el 20 de septiembre de 1869. Esta pieza, sin dejar de ser un objeto suntuario, pertenece a una variante cuya decoración, basada en el azófar y el nielado, carece de la riqueza que caracteriza a otras espadas jinetas, realizadas en marfil o esmalte. Se conservan varias piezas paralelas. Una de ellas, adquirida en Granada en 1812 por la Biblioteca Nacional de París, conserva la divisa de la dinastía nazarí: "Solo Dios es vencedor". El resto de ejemplares, que se encuentran actualmente en distintos museos e instituciones, así como en colecciones privadas, están también datados en el s. XV. Es de acero, empuñadura con decoración esmaltada y nielada ${ }^{27}$, ha sido

25 L.M. LLUBIÁ, Cerámica medieval española, Barcelona, 1973, pp. 82-110; B. MARTÍNEZ CAVIRÓ, Cerámica hispanomusulmana andalusí y mudéjar, Madrid, 1991, pp. 76-77; C. SERRANO GARCÍA, "Los jarrones de la Alhambra", Estudios dedicados a D. Jesús Bermúdez Pareja, Granada, 1988, pp. 127-162; L. TORRES BALBÁS, Arte almohade, arte nazarí, arte mudéjar, Ars Hispaniae, vol. IV, Madrid, 1949, p. 217; y Á. FRANCO MATA, “Jarrón de Hornos”, pp. 146-149, n 4, "Jarrón de la Cartuja de Jerez”, pp. 162-165, nº 10, y “Azulejo", pp. 208-209, no 34, Los Jarrones de la Alhambra. Simbología y poder, catálogo exposición, Granada, 2006.

26 Al-Andalus: las artes islámicas en España, op. cit., 1992, p. 256; Al-Andalus: The Islamic Arts in Spain, Nueva York, 1992; R. AMADOR DE LOS RÍOS, “Acetre arábigo que se conserva en el Museo Arqueológico Nacional”, Museo Español de Antigüedades, vol. VII, Madrid, 1876, pp. 467-481; E. DOMÍNGUEZ PERELA, "Acetres hispanoislámicos", Icónica, 8 (1987), pp. 8-13; Á. FRANCO MATA, "Acetre”, Isabel la Católica. La magnificencia de un reinado. Quinto Centenario de Isabel la Católica, 1504-2004, catálogo exposición, Valladolid-Madrid, 2004, pp. 246-247; y M. GÓMEZ MORENO, op. cit., 1951, p. 337.

27 J. FERRANDIS TORRES, "Espadas granadinas de la jineta”, Archivo Español de Arte, XV (1943), pp. 142-166; Á. FRANCO MATA, "Espada de jineta nazarí, Los Reyes Católicos y la monarquía de España, Granada, 2004, pp. 552-553, n 240; Á. SOLER DEL CAMPO, "Espada jineta", Arte y cultura en torno a 1492, Sevilla, 1992, pp. 159-160, n 74; Á. SOLER DEL CAMPO, "Espada jineta", La paz y la guerra en la época del Tratado de Tordesillas, Madrid, 1994, p. 319, n 255; y Á. FRANCO MATA, "Espada jineta", Museo sin fronteras (2005). 
expuesta en primer plano en una vitrina que alberga un fragmento de cabezada de caballo, comúnmente denominada "novia de Serón", en recuerdo de una hazaña de caballeros camino de dicha localidad almeriense. Es el único resto que queda de una bellísima cabezada desaparecida en 1934, procedente de Lorca (Murcia), de la que hemos incluido una antigua fotografía. Es conocida la afición de la Reina Católica a los arreos de caballo ${ }^{28}$.

La cultura andalusí dejó honda huella en las culturas de la península. La sociedad se componía de un mosaico de confesiones religiosas: musulmanes, cristianos y judíos. Importantes contingentes de mano de obra especializada trabajan para los cristianos importando sus técnicas y tradiciones. Se desarrollan formas artísticas cuya mixtificación entre lo islámico y lo cristiano origina el arte mudéjar. Su estética conquista todos los aspectos de la vida cotidiana: carpintería, yesería, cerámica y tejidos. Aunque escasos objetos pertenecientes a la cultura judía, expuestos en una vitrina exenta, son interesantes un escritorio de madera de nogal ensamblada, recubierta de taracea de hueso, maderas diversas y metal, dos platos de Manises, un amuleto, un talismán y dos anillos signatarios de oro femeninos, uno de ellos con la flor de lis y el otro con la inscripción en caracteres judíos DONA BONA ${ }^{29}$.

Una gran sala de la planta segunda ha sido dedicada a los reinos cristianos, en sus diversas etapas evolutivas entre los siglos VIII y XV. Se van configurando con sucesivos cambios territoriales que concluyen con la hegemonía de los reinos de Castilla y Aragón, protagonistas del avance sobre los territorios en manos del poder musulmán. El avance hacia el sur tras la batalla de las Navas de Tolosa (1212), significa el punto de inflexión a favor de los reinos cristianos hasta la caída definitiva del reino nazarí. En esta última fase se implican activamente las órdenes militares. Diversos hitos histórico-culturales tienen lugar en esta etapa, con la vertebración del camino de Santiago, cuyos peregrinos se llamaban jacobeos, llegados desde distintos puntos de Europa, alcanzando la misma categoría que las peregrinaciones a los Santos Lugares (palmeros) y San Pedro de Roma (romeros). Los siglos finales de la Edad Media traen una nueva apertura a Europa y el Mediterráneo, en línea de máxima a Francia en el s. XIII, el siglo de las grandes catedrales, el XIV, hacia Italia, y el XV hacia Flandes, todo ello motivado por diversas circunstancias políticas y culturales.

La donación más generosa a San Juan y San Pelayo, en León, fue la del rey Fernando I y su esposa doña Sancha el 22 de diciembre de 1063, a raíz del traslado de las reliquias de san Isidoro desde Sevilla, tomando la basílica el nombre del santo taumaturgo visigodo. A la liturgia hispánica mal llamada visigoda y mozárabe remiten los objetos componentes del tesoro, muy mermado y dividido entre la basílica y otras instituciones, particularmente el Museo Arqueológico Nacional. El acta de donación recoge bienes muebles e inmuebles, entre ellos aliam eburneam in similitudinem

28 Á. FRANCO MATA, "Fragmento de cabezada", Museo sin fronteras (2005), "Cabezada de la "novia de Serón"”, Boletín del Museo Arqueológico Nacional, 24-25-26 (2006-2007-2008), pp. 173-184, y "La 'novia de Serón' y su incidencia en el romanticismo”, Alberca, 6 (2008), pp. 249-266.

29 Á. FRANCO MATA, "Antigüedades medievales judías en el Museo Arqueológico Nacional”, Boletín del Museo Arqueológico Nacional, XIII (1995), pp. 103-114. 
nostri Redemptoris Crucifixi, es decir, la famosa cruz de los citados monarcas ${ }^{30}$. Su decoración resume sintéticamente la historia de la salvación, con una intencionalidad funeraria, a partir del evangelio de Mateo. Cristo, con un receptáculo en la espalda, llamado teca, contenedor de la Vera Cruz, es de de cuatro clavos, viste perizoma de pliegues muy bien tallados; a sus pies Adán, causante de la caída del hombre, sale de la tumba y, en la parte superior, aparece Cristo resucitado, según novedosa iconografía. La arqueta de las Bienaventuranzas, en cuyos frentes figuran siete de las ocho bienaventuranzas recogidas en Mt. 5, 1-12, acogió reliquias de santos visigodos ${ }^{31}$. He efectuado una recomposición hipotética a partir de las placas conservadas en el Museo Arqueológico Nacional y otra actualmente en Estados Unidos adquirida a la Colección Larcade, de París ${ }^{32}$. Desgraciadamente, la limitación de espacio ha impedido incluirla en la correspondiente cartela. La cruz y la arqueta han sido montadas en sendas vitrinas exentas, con el fin de ser vistas desde todos los ángulos. Las tres arquetas de plata también en una vitrina exenta, son bien visibles y su disposición conforma un armónico conjunto con las dos piezas eborarias. Se trata de tres arquetas de reducidas dimensiones, de plata, una mozárabe, llamada de las ágatas ${ }^{33}$, y las otras dos de arte de época taifa (422-478 H. / 1031-1086 d.C.). Una de ellas es ovalada, esmaltada y nielada (entre 422 H. / 1031 d.C. y 455 H. / 1063 d.C.). Ya que en las inscripciones no figura ninguna procedencia, la pieza pudo realizarse en cualquiera de los talleres de la época de taifas que se dedicaban a esta actividad. El estilo remite a la taifa de Zaragoza, pues presenta un claro paralelismo decorativo y técnica con el perfumero conservado en el Museo de Teruel. Se observan también similitudes con la placa que enmarca el cierre de la arqueta prismática procedente de la catedral de Zamora, ya indicada. Es presumible que ambos objetos hayan salido del mismo taller. Tanto esta arqueta, como la prismática debieron de llegar a manos del rey Fernando I como parte de un botín de guerra o como pago de impuestos procedentes de alguna de las distintas taifas ${ }^{34}$ (Fig. 6).

La vitrina siguiente acoge los marfiles procedentes del taller de San Millán de la Cogolla, muy disminuidos y fragmentados ${ }^{35}$. Hemos arbitrado, como en otras oca-

30 Á. FRANCO MATA, "El Tesoro de San Isidoro y la Monarquía Leonesa", Boletín del Museo Arqueológico Nacional, IX (1991), pp. 34-68; Á. FRANCO MATA, op. cit. (1998), y "Liturgia hispánica y marfiles. Talleres de León y San Millán de la Cogolla en el siglo XI", Codex Aquilarensis, 22 (2006), pp. 92-144, y "Liturgia y marfiles. Talleres eborarios de León y San Millán de la Cogolla en el siglo XI", A. ARBEITER, C. KOTHE, y B. MARTEN (eds.), Hispaniens Norden im 11. Jahrhundert. Christliche Kunst im Umbruch / El Norte Hispánico en el Siglo XI. Un cambio radical en el arte cristiano, Petersberg, 2009, pp. 257-277, y Á. FRANCO MATA, op. cit., 2010b, pp. 36-57 y 150-165.

31 J.A. HARRIS, "The Beatitudes Casket in Madrid's Museo Arqueológico: Its Iconography in Context", Zeitschrift für Kunstgeschichte, 53 (1990), pp. 134-139.

32 Á. FRANCO MATA, op. cit., 2010b, p. 158.

33 Á. FRANCO MATA, op. cit., 2010a, y Á. FRANCO MATA, op. cit., 2010b, p. 41.

34 R. AMADOR DE LOS RÍOS, op. cit. (1877); Á. FRANCO MATA, "Arte medieval cristiano leonés en el Museo Arqueológico Nacional", Tierras de León, 71 (1988), pp. 27-59; Á. FRANCO MATA, op. cit. (1991), pp. 52-53, y “Arqueta em prata e esmalte", O românico e o Douro, Lisboa, 1998, pp. 146-148; The arts of Islam, Londres, 1976, p. 164; Á. FRANCO MATA, "Arqueta", Museo sin fronteras (2005); y Á. FRANCO MATA, op. cit., 2010b, pp. 45-47.

35 S. DE SILVA Y VERÁSTEGUI, Iconografía del siglo X en el reino de Pamplona-Nájera, Pamplona, 1984, pp. 91-92 y 156-158. 


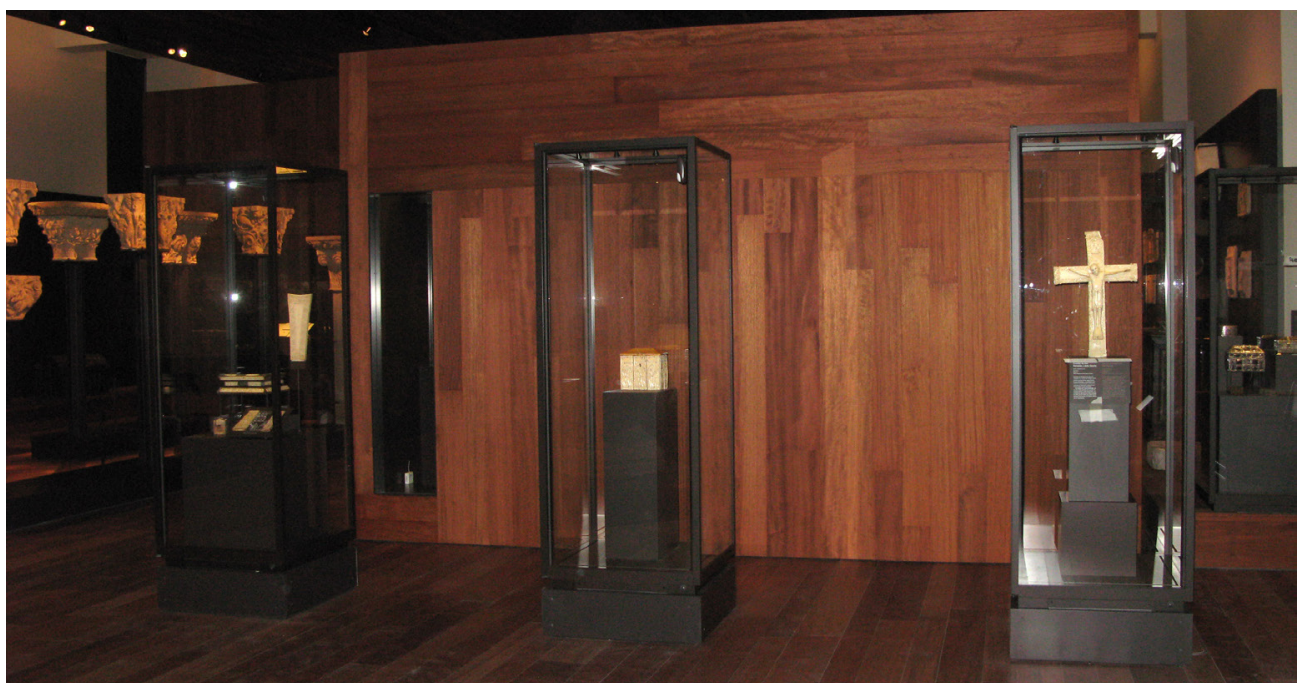

Fig. 6. Eboraria románica de León y San Millán.

siones, la reconstrucción de los dos fragmentos de placa procedentes del arca de San Felices, ingresados en el Museo en distintos momentos ${ }^{36}$. El brazo de cruz mozárabe, de la que se conservan otros dos en el Museo del Louvre ${ }^{37}$, ha sido montado en vertical, pues podría corresponder a la disposición original. De ella he propuesto una reconstrucción hipotética, que he publicado hace unos años y que figura en el interactivo que hemos preparado los componentes del departamento, titulado Eboraria medieval. Estilísticamente responde a la talla de los talleres de Cuenca, como el ara portátil de la misma procedencia ${ }^{38}$.

Los monasterios, siguiendo la regla de San Benito, elegían para su emplazamiento lugares estratégicos y abastecidos de agua, constituyendo microcosmos autosuficientes. Muchos de ellos disponían de scriptoria donde se desarrollaba la actividad de la confección de manuscritos, muchos de ellos iluminados con impresionantes imágenes y espléndidos programas iconográficos, donde los colores fuertes, planos y contrastantes, constituyen la aportación más personal de la iluminación hispánica. Destacan las Biblias y los Comentarios al Apocalipsis del monje lebaniense Beato, que vivió en el s. VIII. Llamados comúnmente Beatos, en honor del autor, figuran entre los tesoros más importantes de monasterios y excepcionalmente de catedrales (Burgo de Osma, Gerona). Aunque su lectura era obligada bajo pena de excomunión entre Pascua y Pentecostés en los monasterios benedictinos, en el s. XII son considerados objetos de prestigio en los monasterios cistercienses. Por esta razón, el Beato de

36 S. MORALEJO ÁLVAREZ, "Placa de marfil del arca de San Felices, con detalle de las bodas de Caná", Boletín del Museo Arqueológico Nacional, VII (1989), pp. 97-99.

37 D. GABORIT-CHOPIN, "Les arts précieux en dehors de Saint-Empire", L'art roman au Louvre, París, 2005, pp. 55-71.

38 Á. FRANCO MATA, op. cit. (1998); Á. FRANCO MATA, op. cit. (2006); Á. FRANCO MATA, op. cit., 2009. 
Cardeña, vilmente maltratado y dispersos bastantes folios de los conservados, tiene unas brillantes ilustraciones ${ }^{39}$. La Biblia de Huesca es un magnífico ejemplar del s. XII, aunque escasamente iluminada contiene textos ajenos al contenido de la misma, como cartas de los Papas Eugenio III (fol. 345v b) e Inocencio III (fol. 346). Entre los folios 300r y 302 se ha intercalado un texto de la obra de Prisciliano, los Canones in Pauli apostoli epistulas a peregrino episcopo emendati (fols. 300r-302v), según ha descubierto M. Conti ${ }^{40}$. De estilo gótico es el Martirologio y Regla de San Benito de las Huelgas, de refinadísima confección y láminas de oros uniformemente distribuidos en las iniciales que inician capítulos ${ }^{41}$, y de la que se conserva otro ejemplar en la Biblioteca Nacional. La encuadernación es excelente ${ }^{42}$. Se han expuesto en una vitrina baja, para una perfecta visibilidad, luz atenuada para no afectar a la conservación y con material para conservar una humedad y temperatura equilibradas.

Los peregrinos medievales recorrieron no solo las rutas de las grandes peregrinaciones, sino otras secundarias, nacidas a veces de aquellas, como San Millán de la Cogolla, emplazado a 16 kilómetros de Nájera. Fue un puesto de avanzada de la reconquista: la leyenda cuenta que el santo se apareció a García Sánchez de Navarra, prometiéndole la victoria en Calahorra en $1045^{43}$. Fue además un centro preclaro de producción de magníficos manuscritos mozárabes. Compostela adquiere un carácter internacional bien definido a partir del s. XI. Aunque con fines penitenciales, de expiación o purificación y cumplimiento de penas, el movimiento de los peregrinos propició el intercambio económico, cultural y artístico, siendo una de las principales vías de transmisión del estilo románico, el primer estilo europeo.

Hemos dedicado una amplia vitrina para exponer objetos vinculados con el culto jacobeo, esmaltes de los talleres de Limoges y Silos. Un dibujo con los principales monumentos del camino, eventualmente con esquemas de los monumentos ilustra la ruta jacobea desde la confluencia de los caminos franceses. Entre los objetos relacionados directamente con la peregrinación figuran los azabaches, procedentes en su gran mayoría de las minas del origen asturiano, en la región de Villaviciosa ${ }^{44}$. Se elaboraron multitud de objetos, de tipo devocional, litúrgico, apotropaico, etc., en este

39 Beato de Liébana. Códice de San Pedro de Cardeña, Barcelona, 2001, con estudios de M. SÁNCHEZ MARIANA, E. ROMERO-POSE (†), E. RUIZ GARCÍA y Á. FRANCO MATA.

40 Á. FRANCO MATA, "Biblia oscense de la catedral", Aragón, Reino y Corona, catálogo exposición, Zaragoza, 2000, pp. 356-357.

41 A. MONTERO TORRES, "Calendario -o Martirologio- cisterciense, y Regla de san benito, del Real Monasterio de santa María de las Huelgas, de Burgos, que se conserva en el Museo Arqueológico Nacional", Cistercium, 173 (1987), pp. 433-447.

42 Á. FRANCO MATA, "Arte románico, gótico y mudéjar en la encuadernación hispánica", Codex Aquilarensis, 26 (2011), pp. 105-138.

43 J.A. HARRIS, "Culto y narrativa en los marfiles de San Millán de la Cogolla", Boletín del Museo Arqueológico Nacional, IX (1991), pp. 69-85.

44 Á. FRANCO MATA, “Azabaches del M.A.N.”, Boletín del Museo Arqueológico Nacional, IV (1986), pp. 131-167, y "Valores artísticos y simbólicos del azabache en España y Nuevo Mundo", Compostellanum, XXXVI (1991), pp. 467-531, recogido en Á. ÁLVAREZ GÓMEZ (coord.), Pensamiento, Arte e Cultura no Camiño de Santiago, Vigo, 1993, pp. 202-267; Á. FRANCO MATA, "Las minas de azabache asturianas y el arte", Actas de las I Jornadas sobre Minería y Tecnología en la Edad Media Peninsular, León, 1996, pp. 91-100, y "Los azabacheros asturianos del siglo XVI. Arte e industria del azabache. Pervivencia", Boletín del Museo Arqueológico Nacional, 19 (2001), pp. 210-225. 
material considerado una joya ${ }^{45}$. Figuras de Santiago peregrino, de diversos tamaños, la Quinta Angustia o Nuestra Señora de Finisterre, rosarios, santos terminados en un extremo en higas.

Los esmaltes románicos tienen un soporte de cobre y la técnica es la del campeado (champlevé). El resultado son obras brillantes y costes relativamente modestos. Los talleres de Limoges conformaron una importantísima industria de esmaltes, donde se elaboraron multitud de objetos, como las arquetas-relicarios, de dimensiones variadas, y el martirio de tres santos medievales muy populares que alcanzaron gran popularidad: San Esteban, Santo Tomás Becket y Santa Valeria. Obras limosinas son un elegante copón, así como dos arquetitas del Museo Arqueológico Nacional, procedentes del monasterio de Villaverde de Sandoval (León), de etapa evolucionada, una de ellas perteneciente al tipo denominado de pacotille ${ }^{46}$. Se esmaltaron también objetos litúrgicos, báculos abaciales y episcopales, y profanos, como los platos aguamaniles (gemellions), vertedor y receptor, de los que aunque el Museo del Louvre cuenta con una colección bastante numerosa, se exhibe una pareja en el Museo Arqueológico Nacional. Su iconografía está vinculada al ciclo artúrico, figurando la coronación de Érec y Énide, rodeados de escenas juglarescas ${ }^{47}$. La enorme producción de los talleres de Limoges eclipsó la importancia del taller silense, cuya calidad es sobresaliente, como una arqueta decorada con clavos esmaltados y una cruz procesional. Se ha contabilizado una cincuentena de excelsos objetos, como el frontal de Silos, un díptico con la Maiestas Domini y la Crucifixión repartido entre el Musée du Moyen Áge, de París, y el Instituto Valencia de Don Juan, de Madrid ${ }^{48}$. También se realizaron objetos siguiendo la técnica limosina: Cristo crucificado, candelabro, portapaz, naveta, cubierta de evangeliario.

En la Baja Edad Media la nobleza alcanza un alto grado de poder; de hecho, el del rey está muy mediatizado por dicho estamento. Continúa el impulso de la repoblación. Gran parte de las tierras son entregadas a la nobleza y las órdenes militares. Los castillos se hacen residenciales y aumenta el lujo de los palacios nobiliarios, adoptando el estilo ornamental islámico. Eventualmente se construyen palacios en contextos monásticos y conventuales. Proliferan los escudos como enseñas de la nobleza. Como ostentación de clase, utilizan adornos colgantes, denominados pinjantes, de metales nobles, de tamaño y forma variados. Su destino era enjaezar los caballos de las familias de la realeza y la nobleza, cuya heráldica ostentan. Presentan eventualmente el anverso esmaltado. Los temas decorativos son varios, mostrando leyendas

45 B. GILMAN PROSKE, The use of jet in Spain, Madrid, 1966.

46 L. JOUHAUD, "Les chasses de "pacotille"”, Bulletin de la Société Archéologique et Historique du Limousin, 83 (1949), pp. 48-75.

47 Á. FRANCO MATA, "Érec y Énide en una pareja de gemellions del Museo Arqueológico Nacional”, Codex Aquilarensis, 23 (2007), pp. 118-133; y J.J. MARQUET DE VASSELOT, "Les gemellions limousins du XIIIème siècle", Mémoires de la Société Nationale des Antiquaires de France, 3 (1951), pp. 1-126.

48 M.M. GAUTHIER, "L'atelier d'orfèvrerie de Silos à l'époque romane", El Románico en Silos. IX Centenario de la consagración de la iglesia y claustro 1088-1988, Abadía de Silos, 1990, pp. 377-395; Á. FRANCO MATA, "Orfebrería y esmaltes del taller de Silos", Actas del Congreso internacional sobre la Abadia de Santo Domingo de Silos. Milenario del Nacimiento de Santo Domingo de Silos (1000-2001). Sección de Historia del Arte, Abadía de Silos, 2003, pp. 149-210. 


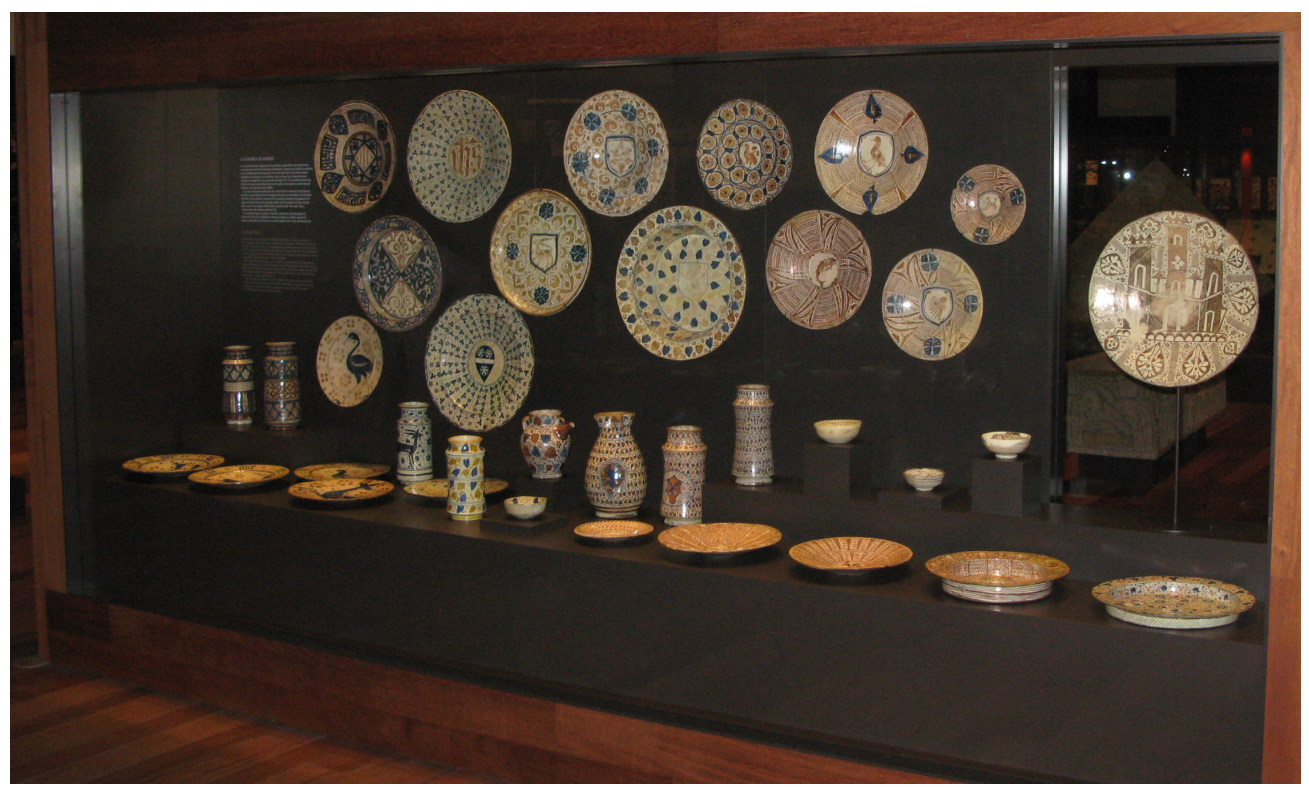

Fig. 7. Cerámica de Manises.

y lemas, iniciales, temas heráldicos y ornamentales. Se conservan en abundante número, engrosando las colecciones de museos e instituciones. El Instituto Valencia de Don Juan atesora una importante colección de estilo gótico ${ }^{49}$. El Museo Arqueológico Nacional reúne más de doscientos, procedentes de la colección Gudiol ${ }^{50}$. En el marco caballeresco se exhibe una espada del s. XV con inscripción en el pomo y en los gavilanes en caracteres góticos la advocación mariana: AVE GRATIA PLENA ORA PRO NOBIS, muy frecuente en los más variados contextos.

Hemos dedicado un capítulo a la configuración de la ciudad medieval, destacando entre las artes suntuarias la espléndida serie de la cerámica valenciana ${ }^{51}$, Paterna y sobre todo Manises. La cerámica de mayor riqueza es la loza dorada, cuyos alfares más importantes se encontraban en la villa de Manises (Fig. 7). Comenzaron a imitar la cerámica nazarí malagueña desde el segundo cuarto del s. XIV, con decoración geométrica, atauriques y otros motivos, como escudos. La época de mayor esplendor corresponde a una gran parte del s. XIV y XV, en que la decoración islámica da paso a los elementos de carácter gótico. Hay motivos exclusivamente dorados o mezclados con azul cobalto. Las series decorativas principales son: "Ave María" y variantes; Hojas de brionia o nueza blanca; Atauriques carnosos con rosas góticas;

49 M.L. MARTÍN ANSÓN, La colección de pinjantes y placas de arnés medievales del Instituto Valencia de Don Juan, Madrid, 2004.

50 F. DE OLAGUER Y FELIÚ, "La colección de pinjantes y piezas de jaez de caballo medievales del Museo Arqueológico Nacional de Madrid”, Boletín del Museo Arqueológico Nacional, XI (1993), pp. 89-106.

51 Á. FRANCO MATA, L.J. BALMASEDA, I. ARIAS y C. PAPÍ, "Documentación de las cerámicas valencianas medievales en el Museo Arqueológico Nacional, La cerámica de Paterna. Reflejos del mediterráneo, catálogo de la exposición, Valencia, 2002, pp. 106-118. 
Hojas de hiedra; Hojas de carrasca; Naranjas partidas o margaritas; Hojas de helecho; Notas musicales (solfa); Enrejado; Retícula, hojas cardo y rosas góticas; Retícula y espirales; "De monja"; Combinaciones de distintas series. En ocasiones figuran escudos de familias comitentes, como Despuig, Alanya, Nasi o Tedaldi. Destaca el plato con castillo rodeado de bandas reticuladas y de la hamsa, y reverso con flor de lis y hojas de helecho. Dentro de la cerámica mudéjar es importante la producción de azulejos destinados a la decoración de solados y paramentos. En los talleres de Manises abundan los decorados con los símbolos de los gremios: herradores, tejedores de velos, carreros, zapateros, constructores o canteros, curtidores, peraires, pasamaneros y carpinteros. Alguno de carácter religioso o los que ostentan divisas o lemas caballerescos.

Con el título de "Triunfo de la imagen: iglesias y catedrales" se analizan los templos en el marco urbanístico: las iglesias se emplazan en el centro de las ciudades y les confieren su peculiar conformación. La estructura generalizada de cruz latina es el referente simbólico de la iglesia, que convive con otras tipologías como la planta circular. Dicha estructura se refleja en el objeto cristiano por excelencia: la cruz, que constituye el fundamento de la fe y preside las celebraciones. Tres cruces góticas dominan la parte superior de la vitrina exenta, entre las que destacan dos de plata. Una tiene marca de Morella, y presenta una ejecución muy elegante ${ }^{52}$. La otra, aunque procedente de Asturias, es castellana, está marcada con marca de Burgos y es obra de hacia 1400, similar a otra del Museo Diocesano de Palencia, procedente de Requena de Campos $^{53}$. Siguiendo las disposiciones del abad Suger en relación con el tesoro de Saint-Denis, se pone especial énfasis en realzar la belleza del ritual con vasos y ornamentos sagrados de materiales nobles y elegantes formas ${ }^{54}$. Cálices, patenas, navetas y otros recipientes ostentan programas iconográficos más o menos densos. Los largos ceremoniales se acompañaban de textos litúrgicos recogidos en códices eventualmente con ilustraciones alusivas a las festividades correspondientes. Una vitrina exenta acoge diversos objetos de plata y metales más modestos. Se exponen varios cálices: uno de plata decorado con medallones esmaltados relacionados con la orden franciscana. La marca del platero real ALO/NSUS lo vincula a los Reyes Católicos. Cáliz del mismo material decorado con ramas vegetales típicas del gótico final, firmado por Juan Díaz. Un tercer ejemplar es de pie hexagonal estrellado y decoración vegetal. Un pie de cruz o relicario de estructura prismática hexagonal sobre seis leones, ha sido reaprovechado como salero; marca de la ciudad de Barcelona. Hostiario con inscripción mariana en el cuerpo del recipiente y cristológica en la tapa; marca de Burgos. Dos crismeras, una de ellas con marca de Toledo. Un elegante relicario con figura de ángel, que peina cabellera de plásticos bucles dorados y va ataviado con alba litúrgica (Fig. 8).

52 J.M. CRUZ VALDOVINOS, Catálogo de la platería del Museo Arqueológico Nacional, Madrid, 1982 , pp. 44-48.

53 Á. FRANCO MATA, "Un tipo de cruz de plata de taller burgalés del siglo XV y probables derivaciones", Boletín del Museo Arqueológico Nacional, XII (1994), pp. 113-130.

54 Le trésor de Saint-Denis, catálogo de la exposición, París, 1991; y D. GABORIT-CHOPIN, Regalia. Les instruments du Sacre des rois de France. Les “honneurs de Charlemagne”, París, 1987. 


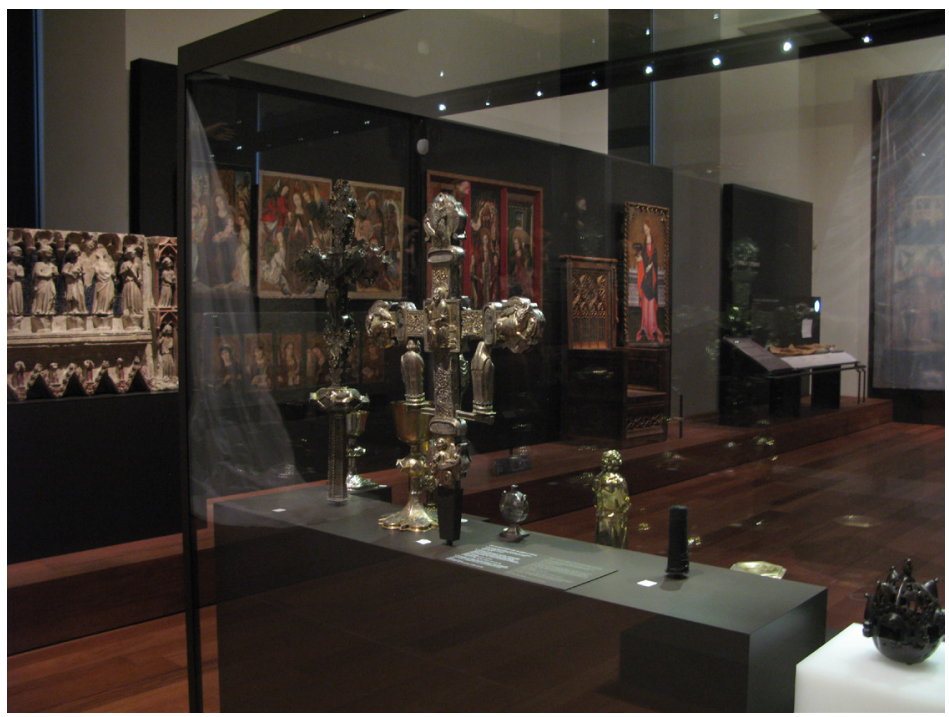

Fig. 8. Objetos litúrgicos góticos.

Hemos dedicado un amplio capítulo a los ritos y símbolos funerarios. Aunque no es el momento de ampliar en este tema, conviene recordar los atuendos funerarios del infante don Felipe, levantisco hermano del rey Alfonso X el Sabio, y su esposa Inés de Guevara y Cisneros. Fueron exhumados de sus sepulcros de la iglesia templaria de Santa María la Blanca, de Villalcázar de Sirga (Palencia), de los que mostramos imágenes. Los atuendos están en una vitrina exenta. La capa que envolvió el cadáver del infante es una de las piezas de indumentaria más representativas del s. XIII, obra nazarí decorada con motivos de lacería, rematado en bandas ornamentales epigráficas con la conocida inscripción baraka (felicidad), en caracteres cúficos. El bonete está decorado con cuadrifolios y motivos heráldicos de castillos y águilas repetidos con ritmo mudéjar. Las águilas imperiales aluden a su madre, doña Beatriz de Suabia. Realizados con seda y oro. El cojín pertenecía a doña Inés, presenta dos caras similares, cada una formada por cuatro cuadrados de color crudo amarillento y negro amoratado, escaqueados y cosidos; la decoración ajedrezada alude a la heráldica de doña Inés. Es de seda (Fig. 9).

Finaliza el recorrido de la vista a las salas de medieval con el capítulo titulado "Una nueva apertura a Europa". A lo largo de la Baja Edad Media, los reinos peninsulares cristianos están vinculados al resto de Europa: en el s. XIII a Francia fundamentalmente, en el XIV a Italia, sobre todo los territorios de la Corona de Aragón, por lazos dinásticos con Nápoles, Sicilia y Cerdeña, por un activo comercio con Toscana, y por las relaciones del alto clero con la Santa Sede. En el s. XV los reinos peninsulares expanden sus redes al norte de Europa, movidos en parte por el comercio de la lana. El florecimiento del arte flamenco y sus líneas de devoción se trasladan a Castilla. Flandes fue la cuna de numerosos artistas que desplegaron su arte en España. Inglaterra exportó sus conocidos alabastros, que a pesar de su carácter eminentemente 


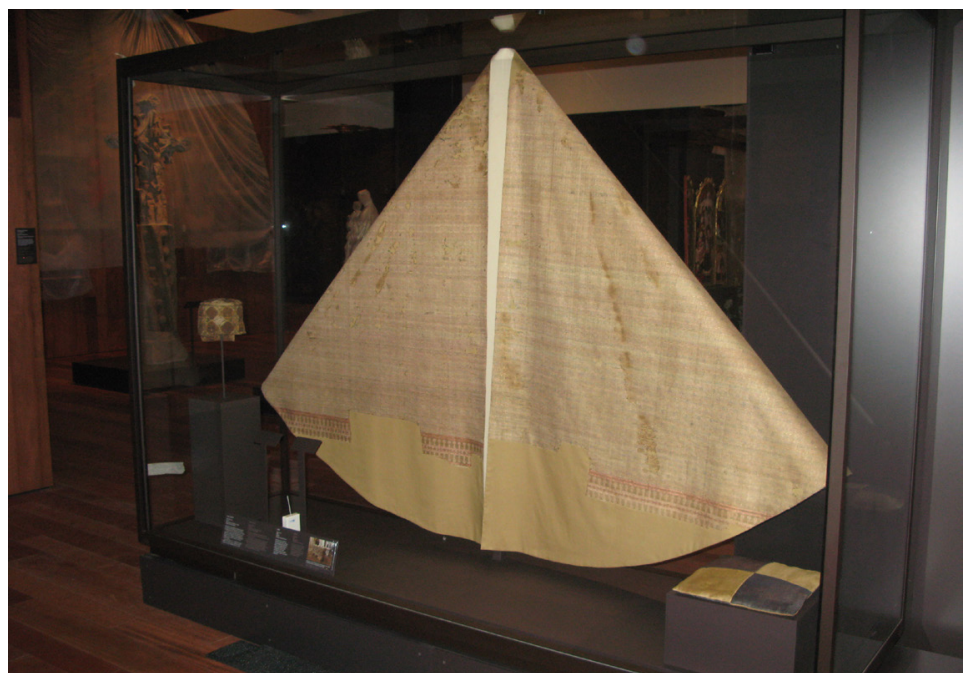

Fig. 9. Capa y bonete mortuorios del infante Don Felipe y cojín mortuorio de su esposa doña Inés de Guevara y Cisneros.

industrializado tuvieron gran aceptación. Dos siglos antes floreció un tipo especial de tejido denominado opus anglicanum, caracterizado por una puntada hundida junta y pequeña que realza el matizado de los colores y da sensación de relieve ${ }^{55}$. El Museo conserva una capa del s. XIV, llamada de Daroca, por haber sido donada a la colegial de Daroca por el papa Benedicto XIII ${ }^{56}$. Se ha representado un programa salvífico a partir de la Creación, siguiendo con la Encarnación y Pasión de Cristo, cuyos méritos han proporcionado la salvación del cristiano. Está confeccionada a base de lino, seda y oro.

Hemos dedicado una vitrina a mostrar preseas procedentes de Europa y pertenecientes a distintos estilos. Vinculadas con Renania son una serie de placas románicas de relicario, recompuestas para formar una puerta de sagrario barroca. Su procedencia del monasterio de Santa Clara, de Santiago de Compostela, sugiere una donación de un peregrino jacobeo ${ }^{57}$. Dos peines litúrgicos góticos procedentes de Egipto eran usados en las grandes ceremonias. Constan de lendrera, escarpidor y cuerpo central decorados con temas evangélicos correspondientes a los ciclos de navidad y pasión

55 S. GREENUP, “Mabel: l'arte del ricamo in Inghilterra", E. CASTELNUOVO (coord.), Artifex bonus. Il mondo dell'artista medievale, Roma-Bari, 2004, pp. 129-137.

56 R.M. MARTÍN I ROS, La capa de Daroca y los ornamentos de la colegial, Daroca. Fiestas Corpus Christi, 2003, Daroca, 2003; y Á. FRANCO MATA, "Un ejemplar de opus anglicanum en el Museo Arqueológico Nacional. La capa de Daroca, donación del Papa Luna a la colegial de Santa María", Patrimonio Artístico de Galicia y otros estudios. Homenaje al Prof. Dr. Serafín Moralejo Álvarez, vol. III, Santiago de Compostela, 2004, pp. 81-86.

57 Á. FRANCO MATA, "Texto e iconografía y aspectos religiosos culturales en una tipología de arquetasrelicario románicas de talleres renanos", Codex Aquilarensis, 25 (2009), pp. 35-79. 


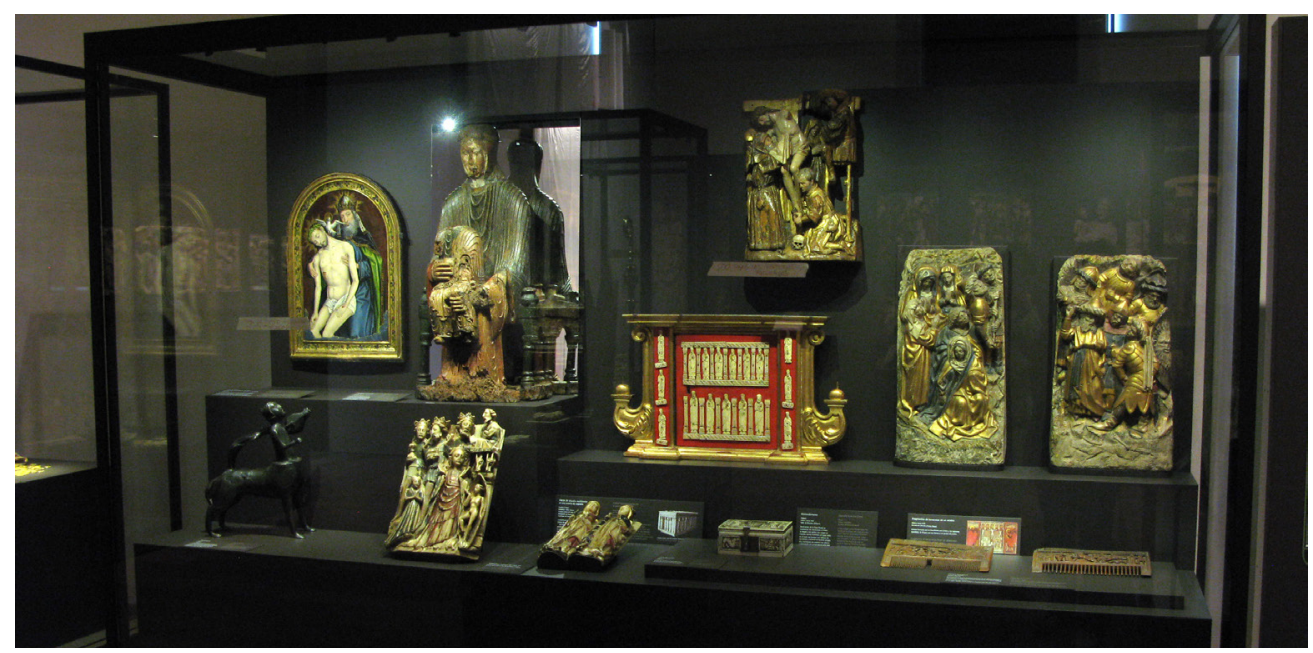

Fig. 10. Nueva apertura a Europa.

respectivamente ${ }^{58}$. Una caja de juego de alma de madera, revestida con planchas de hueso decoradas con figuras humanas y animales; tablero de escaques en la cara de la base. Es obra de taller flamenco del s. XV (Fig. 10).

Hemos expuesto en una vitrina individual un hermoso tapiz con la Virgen con Niño y ángel, que formó parte de la serie donada por el arzobispo Alfonso de Aragón, hijo del rey Fernando el Católico, a la Seo de Zaragoza. Los personajes se hallan en un vergel con numerosos detalles de objetos y seres simbólicos. La iconografía está inspirada en modelos de Alberto Durero. Las iniciales P E A aluden a un tejedor de Bruselas. Está tejido en lana, seda e hilos de oro. Es obra anterior a 1515.

Una elegante vitrina exenta ha sido dedicada a exponer marfiles góticos franceses e italianos. Los primeros destacan en el panorama internacional por su extraordinaria calidad. La escuela parisina de la segunda mitad del s. XIII desarrolló una temática religiosa, sobre todo mariana, en figurillas de bulto redondo. Catedrales, iglesias y monasterios se inundaron de dípticos y trípticos con episodios evangélicos, transposición de la escultura monumental. La estética del s. XIV se suma a la temática profana, sobre todo asuntos amatorios. El Museo Arqueológico Nacional tiene algunas obras sobresalientes, como una placa con la escena de los Reyes Magos, del s. XIV. La Resurrección y Juicio Final conforman la iconografía de un ala de díptico, con la correspondiente placa desaparecida que presentaba escenas de la Navidad y la Epifanía. Taller parisino de comienzos del s. XIV. Del Maestro de Kremsmünster (presumiblemente activo en Maguncia, Alemania) es el díptico de la Pasión, Entrada de Cristo en Jerusalén, Santa Cena, Traición de Judas, Lavatorio, Oración en el huerto y Crucifixión. Se trata de un tipo de gran éxito en Europa a juzgar por la abundante serie de dípticos conservados: catedral de Oviedo, Berlín, Baltimore. Otros dípticos cercanos

58 Á. FRANCO MATA, Museo Arqueológico Nacional. Catálogo de la escultura gótica, $2^{\mathrm{a}}$ ed. Madrid, 1993, pp. 215-217, nº 267-268. 


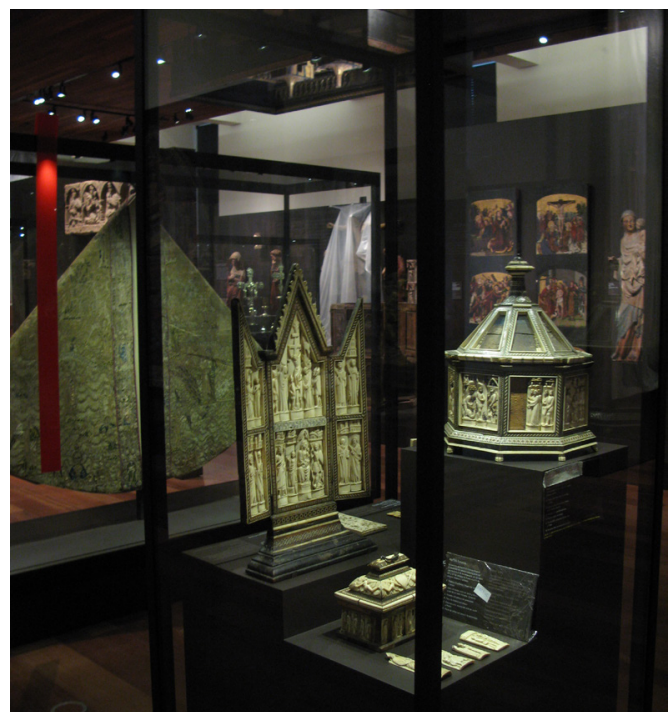

Fig. 11. Marfiles del taller de los Embriachi.

desde el punto de vista estilístico varían en cuanto al contenido del programa iconográfico, con la representación de la vida de Cristo con el ciclo de Navidad, Pasión y Triunfo de la Virgen ${ }^{59}$. Es obra refinada de marfil, del último cuarto del s. XIV.

La carestía del marfil en Francia propició el desarrollo de talleres italianos entre los que destaca el de los Embriachi, entre los siglos XIV y XV, un cuarto de siglo aproximadamente. Se tallaban en hueso objetos de carácter religioso y profano. El magnífico tríptico con la Crucifixión, Virgen con el Niño y santos repite la temática de otros, con variantes debidas al deseo de los comitentes. Se tallaba cada placa independientemente, de manera que era fácil acoplarlas a gusto del destinatario ${ }^{60}$. Un cofre de bodas, ciclo de Jasón y Medea y una de las siete Virtudes, la Templanza, ya que se han perdido las seis restantes, teologales y cardinales, procedente de Zaragoza, forma parte de los cofres amatorios decorados con temática clásica, como el ciclo de la juventud de Paris y otros, inspirados en el Roman de Troie (ha. 1160-65), colosal obra de más de treinta mil octosílabos, de Benoît de Saint-Maure, y la Historia destructionis Troiae, de Guido delle Colonne, prosa latina compuesta entre 1272 y 1287. Un tercer texto, el Excidium Troiae, fue escrito probablemente entre el s. IV y el VI, y narra la vida de Paris antes de desencadenarse la guerra ${ }^{61}$ (Fig. 11).

Como colofón, aludiré a la última vitrina, exenta, dedicada a orfebrería. Está presidida por el báculo del Papa Luna, Pedro Martínez de Luna, miembro de la pode-

59 R.H. RANDALL et al., Masterpieces of Ivory from The Walters Art Gallery, Nueva York-Baltimore, 1985, p. 218 , fig. 312.

60 M. TOMASI, Monumenti di avorio. I dossali degli Embriachi e i loro commitenti, Pisa, 2010.

61 Á. FRANCO MATA, "Cofres de bodas del taller de los Embriachi, con especial referencia a los conservados en España”, Fiestas, juegos y espectáculos en la España Medieval. Actas del VII Curso de Cultura Medieval, Aguilar de Campoo (Palencia), Madrid, 1999, pp. 113-132. 


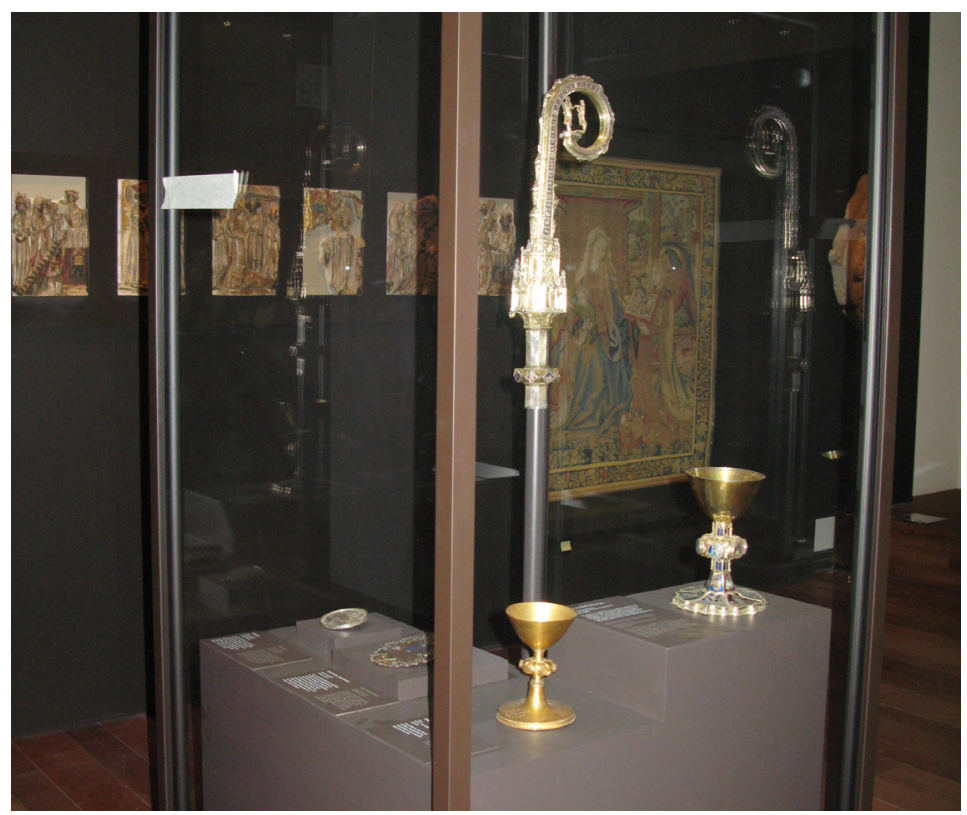

Fig. 12. Báculo del Papa Luna.

rosa familia de Luna, accedió a la sede papal con gran polémica (Benedicto XIII, 1378-1417). Hombre de gran cultura, se doctoró en Derecho en Montpellier y escribió varios tratados de carácter ascético. Vivió una época convulsa y de graves enfrentamientos políticos. La resolución del llamado Cisma de Aviñón (o Cisma de Occidente) provocó su deposición en el Concilio de Constanza en 1417, fecha en que se retiró a Peñíscola hasta su muerte en 1423. El báculo, de hacia 1342, perteneció a su antecesor Clemente VI, siendo reformado hacia 1393 bajo el pontificado de Benedicto. En el remate de la rosca figura el grupo de la Anunciación sobre peana, y la superficie está decorada con cenefa esmaltada. Tiene marca de Aviñón: llaves cruzadas de oro sobre menguante de plata, tiara con ínfulas de sinople sobre menguante de plata. Es de plata dorada y esmaltes, y procede de Zaragoza $^{62}$ (Fig. 12). Joya de la orfebrería europea es el cáliz de Estrasburgo, de copa muy abierta y lisa, astil hexagonal con ventanas ciegas de tracería gótica y fondo de esmaltes. La iconografía plasma conceptos teológicos, el Doble Credo, cuyo origen iconográfico se rastrea en la orfebrería de la cuenca del Mosa en el s. XII. Tiene marca de Estrasburgo. Es de

62 J.M. CRUZ VALDOVINOS, op. cit., 1982, pp. 38-41, y "Báculo de Benedicto XIII, el Papa Luna", Exposición Canciller Ayala, catálogo, Vitoria, 2007, pp. 334-335; Á. FRANCO MATA, "Báculo del papa Luna", Aragón, Reino y Corona, op. cit., 2000, p. 358, no 155, y “Báculo del Papa Benedicto XIII", La Huella y La Senda, catálogo exposición, Las Palmas de Gran Canaria, 2004, pp. 106-107, y "El Papa Luna y el arte de su tiempo", Almogaren. Revista del Instituto Superior de Teología de las Islas Canarias (Sede Gran Canaria). X Jornadas de Historia de la Iglesia (VI Centenario de la Diócesis Canariense y Rubicense), 34 (2004), pp. 83-115. 
plata dorada y esmaltes translúcidos, datado en $1360^{63}$. Contraste con este forma el pequeño y modesto cáliz de cobre, que como el anterior, tiene copa abierta y lisa, de pie circular y macolla del tipo característico de la segunda mitad del s. XIV.

Los ornamentos litúrgicos constituían la plasmación en imágenes de las verdades teológicas. El mal llamado broche, pues es un formal, de capa pluvial usada en las festividades se decora con el Árbol de Jesé o genealogía de Cristo. Es obra del Maestro del tríptico de Orléans, autor de otras placas conservadas en el Museo Lázaro Galdiano. Cobre y esmaltes. S. XV ${ }^{64}$. Finalmente, se expone un medallón, con la Dormición de la Virgen o Koimesis. Aunque la fiesta de la Dormición, Asunción y Coronación de la Virgen es de origen bizantino, el culto se expande a Occidente y tiene amplio reflejo en el arte. Inscripción en caracteres góticos alusiva a la Asunción: ASSUMPTA: EST: / MARIA: IN CELUM: / GAUDENT: ANGELI: / B: ESTO: FORTIS. Es de plata y está esmaltado en colores translúcidos. Obra limosina del s. XIV. Este conjunto constituye un espacio armónico y un remanso estético para la vista.

63 J.M. CRUZ VALDOVINOS, op. cit., 1982, pp. 35-37; Á. FRANCO MATA, "El 'Doble Credo' en el arte medieval hispánico", Boletín del Museo Arqueológico Nacional, XIII (1995), pp. 119-136.

64 M.L. MARTín ANSÓN, "El Maestro del Tríptico de Orleans en el museo Lázaro Galdiano y museo Arqueológico Nacional”, Goya, 202 (1987), pp. 200-206. 